\title{
Robert Bellah, religion og menneskelig evolution
}

\author{
HANS J. LUNDAGER JENSEN
}

\begin{abstract}
ENGLISH ABSTRACT: Introduction to and discussion of Robert Bellah's major book, Religion in Human Evolution (2011). which defines and describes tribal religion (religion in pre-state societies), archaic religion (religion in early states) and religious currents in the axial age, the period in the middle of 1st mill. BC, where new radical and intellectual ideas and practices, sceptial or world renouncing, appeared in China, India and Greece. Hopefully, Bellah's book will be a standard reference work in the academic study of religion and an inspiration for the history of religion in the future to engage in historical and comparative studies.
\end{abstract}

DANSK RESUMÉ: Introduktion til og diskussion af Robert Bellahs hovedværk fra 2011, Religion in Human Evolution, der definerer og beskriver tribal religion, dvs. religion $i$ før-statslige samfund, arkaisk religion, dvs. religion $i$ tidlig-statslige kulturer samt religiøse strømninger $i$ aksetiden, perioden i midten af 1. årt. f.Kr., hvor nye radikale og intellektuelle, skeptiske eller verdensafvisende, tankegange og livsformer formuleres $i$ Kina, Indien og Grækenland. Bogen bor betragtes som et hovedværk $i$ aktuel religionsforskning, og den vil forhåbentlig kunne inspirere religionshistorien til også at drive historisk-komparativ forskning.

KEYWORDS: Robert Bellah; history of religion; cultural evolution; tribal religion; archaic religion; axial age

Religion in Human Evolution. From the Paleolithic to the Axial Age fra 2011, skrevet af Robert Bellah, en af de helt store blandt det 20. årh.s religionssociologer, vil formentlig, og forhåbentlig, blive et generelt og uomgængeligt referenceværk for religionshistorien i mange år fremover. Man vil givetvis kunne kritisere den for en hel del, hvad detaljer angår, og eksempler på det vil også komme længere nede i denne anmeldelse. Men det vigtige er, at bogen er et bud på en religionshistorie - altså ikke en religio- 
nernes historie, ikke kun eller ikke primært en oversigt over forskellige religioner i fortid og nutid og over udvalgte religionsfænomenologiske tyngdepunkter, men en religionens historie. Robert Bellah tør tænke stort; hans bogs historie begynder med den virkelige begyndelse, den før hvilken intet var. Til gengæld strækker den sig op kun til 'aksetiden', dvs. til et tidsrum i midten af 1. årt. f.Kr., hvor muligheden for kritisk afstandtagen til hidtil uproblematiske verdens- og normopfattelser og for muligheden for alternative forklaringer og leveformer dukkede op omtrent samtidig og, tilsyneladende, uden gensidig forbindelse i Kina, Indien og Middelhavsområdet. ${ }^{1}$ Den handler derfor ikke om de store skrift- og/eller verdensreligioner, dvs. ikke om jødedom, kristendom eller islam eller om buddhismen som verdensreligion, de religioner, der har domineret de sidste to tusinde år. Denne historie mangler stadig at blive skrevet, og Religion in Human Evolution er dermed ikke en hel, kun en halv, religionens historie. Men det ændrer intet ved bogens principielle betydning.

Kort fortalt består bogen af to kapitler om religion generelt og syv kapitler om religionens historie. De to første kapitler angår religionens mulige opståen som del af en human evolution forud for tilkomsten af den nuværende menneskeart, homo sapiens. De syv følgende kapitler plus en afsluttende konklusion beskriver religionens historie fra stammesamfunds religionsform via begyndende statsdannelsers og tidlige, egentlige staters religionsform op til den såkaldte 'aksetids' religioner i midten af det første årtusinde f.Kr.: det gamle Israel, Grækenland, Kina og Indien. Centralt placeret er kapitel 6, "The Axial Age I" med en teoretisk diskussion af indholdet i og berettigelsen af at operere med en 'aksetid'. Bogen er skrevet, så den er almen tilgængelig, og der er dækkende henvisninger til relevant faglitteratur. I lange stræk skriver argumentationen videre på anden, forudgående forskning. Robert Bellah er strengt taget ikke 'ekspert' i nogle af de religioner, der inddrages som eksempler, så fremstillingen støtter sig gennemgående på et kvalificeret udvalg af anerkendte specialister. Det lykkes til gengæld godt; dette er en bog, der også kan læses som en serie introduktioner til de kulturer og religioner, der inddrages som eksempler. ${ }^{2}$

\section{Begreberne 'evolution' og 'religion'}

Begrebet 'evolution', prominent også i bogens titel, strækkes så vidt som overhovedet muligt: Kulturel evolution ses som en kontinuerlig fortsættelse af biologisk evolution, der på sin side forbindes med en ikke-biologisk, fysisk evolution, der tager sin

\footnotetext{
Ud over Bellahs bog her er nu grundliggende: Robert N. Bellah \& Hans Joas, eds., The Axial Age and Its Consequences, (2012); jf. Anders Klostergaard Petersens anmeldelse i dette nr. af RvT. Jf. også Lundager Jensen 2011.

2 Bellahs redegørelser for historiske religioner er overordnet set plausibel. I en seminarrække i 2012 ved Religionsvidenskab ved Aarhus Universitet læstes bogen af ansatte med indsigt i de kulturer og delhistorier og dertil hørende forskningstraditioner, der inddrages i bogen, og den gennemgående vurdering af dens valg af faglige autoriteter og af hele fremstillingens gehalt var positiv. Uenigheder og afvigende vurderinger angik specifikke detaljer.
} 
begyndelse ved big bang. Bellah hører altså til dem, der vil rehabilitere en big eller deep history (s. xi); historie er hele historien, henover traditionelle skel mellem historie og arkæologi, og mellem menneskeartens og andre arters historie. Her er der altså ingen kategorial forskel mellem 'historie' og 'præhistorie'; i en eksplicit Hegelinspireret vision (jf. det indledende motto s. ix) ses kulturen som oprindeligt udviklet i en coevolution med menneskeartens biologiske evolution (ibid.), og menneskearten er resultatet af den biologiske evolution, der begyndte med den første bakterielignede organisme. Det er organismer, ikke gener alene, der undergår evolution; forskellen er, at organismer kan lære og dermed ændre deres omgivelser og derved aktivt indvirke på deres egne efterkommeres overlevelsesmuligheder (s. xiii). Bellah synes heller ikke at regne med en kategorial forskel mellem 'historie' og 'evolution'; den biologiske verdens historie er evolution (s. xi), og den menneskelige historie er en umiddelbar fortsættelse og forlængelse af den biologiske historie.

Religionsbegrebet i bogen er grundlæggende det, som Clifford Geertz (1966) formulerede i den berømte artikel om religion betragtet som et kulturelt system (s. xiv), altså et sæt af symboler, der formulerer et internt selvreferentielt 'system', der omfatter dels en ontologi, dels et sæt af etiske og æstetiske normer, og som opretholdes i kraft af en rituel praksis, hvis emotionelle indflydelse giver 'systemet' plausibilitet for de mennesker, der deltager i den. Denne definition, som ikke indeholder bestemte forestillingsindhold, fx om 'transempiriske aktører', var en variation af Emile Durkheims religionsdefinition, og det er også i denne tradition, Bellah gennemgående og eksplicit placerer sig (jf. s. 130. 265. 484f.). Religion er altså grundlæggende et kommunikativt fænomen, et sæt af tegn, der udveksles mellem et antal menneskelige organismers bevidstheder og som konstituerer disse mennesker som en særlig gruppe. Andre forskere i samme tradition, som Bellah støtter sig til, er Roy A. Rappaport (s. 145) og Randall Collins (s. 279).

Dertil kommer en psykologisk dimension, som bogen indledes med (på grundlag af psykologiske autoriteter). Som bevidsthedsfænomen er religion i sagens natur involveret i et antal centrale, humane kognitive og emotionelle processer, måske dem alle. Det er i hvert fald Bellahs tilgang. I en typologi over 'religiøse repræsentationer' kan man sondre fire typer (s. 13f.): (1) 'forenende (unitive) repræsentationer', dvs. erfaring - hvis man kalde det det - af organismens enhed med sine omgivelser; (2) 'handlingsorienterede (enactive) repræsentationer', dvs. kropslig gestik, knæle, bukke, rejse sig op osv. som afsender af meddelelser; (3) symbolske (dvs. sproglige, narrative) repræsentationer; og (4) begrebslige repræsentationer. Disse fire typer repræsentationer svarer selvfølgelig til mystik, ritual, mytologi og teologi som fire domæner inden for religion; samtidig udtrykker rækken 'ontogenetiske' faser, dvs. faser i et menneskes personlige udvikling, fra fosteret til den alfabetiserede unge eller voksne - men vel at mærke faser, som akkumulerer, ikke afvikler (s.13). Det menneske, som kan tænke 'teologisk', er fortsat en krop, der kan henfalde til en følelse eller en erfaring af, at den svinder hen og opløses i sine omgivelser. Særlig den handlingsori- 
enterede har Bellahs interesse; det er her, man finder dén form for handling, som vil være Bellahs bud på den mest enkle sociale handling, 'socialitetens fødsel' så at sige: musikken. Mennesket er det eneste dyr, der kan klappe i takt (s. 24-27. 127f.).

Afgørende for Bellahs overordnede argumentation er imidlertid, at han forbinder den bio-kulturelle evolutionsteori med den grundlæggende Durkheimske religionsforståelse igennem Merlin Donalds teori om udviklingen af de specifikt menneskelige kommunikationsformer - som i Bellahs konstruktion er en art fylogenetisk korrelat til de fire psykologiske domæner eller til de sidste tre af de fire. Donalds faser: først mimetisk (forud for homo sapiens) og 'mytisk' (dvs. sproglig) kommunikation (i og med homo sapiens) er det, der adskiller mennesker fra andre dyrearter, og disse to kommunikationsformer (Donald kalder det 'kulturer') er til stede i al menneskelig kommunikation, inklusive den nutidige (jf. Lundager Jensen 2008). Her er der basale, humane kommunikationsformer, som er materialet for al menneskelig kollektiv aktivitet, inklusive religion. Enhver religion vil altså indbefatte mimetisk og sproglig kommunikation. Et særkende ved Donalds udviklingsmodel er, at han tilføjer en særlig 'teoretisk kultur' som den seneste fase, dvs. den kommunikative aktivitet, som indbefatter og forudsætter samtidig brug af eksterne tegn, primært visuelle. Skrift indebærer en enorm forøgelse af kommunikationens effektivitet, såvel i en konkret betydningsdannelse (med flere participerende bevidstheder, der tilsammen i kommunikationssituationen danner et trans- og hyperindividuelt subjekt, formidlet af eksterne tegn fx på en tavle eller et dokument) som i genkaldelse af lagret betydning (ved konsultation af biblioteker, arkiver etc.). Det er skriftligheden, der giver muligheder for dannelse af begreber, konstruktion af komplekse argumentationskæder og dannelse af teoretisk forklaring. Donald selv vil først regne med en almen teoretisk kultur fra og med alfabetiseringen af brede dele af en befolkning, altså for den vestlige verdens vedkommende fra og med 1800-tallet. Bellah derimod fokuserer på dannelsen af en intellektuel elite i midten af 1. årt. f.Kr., et samfund af mennesker, der har levet indlejret $\mathrm{i}$ en verden af skrift sammenlignelig med den moderne erfaring. Denne elite har givetvis kun omfattet en numerisk meget lille andel af en given population. ${ }^{3}$ Men det var den, der var ansvarlig for brudene med de etablerede forståelsesordener, der havde domineret indtil da, og som med sit brud - sine forskellige alternativer - udgjorde afsættet til det, som er blevet til den moderne verden. For Bellah er aksetiden identisk med, og skyldes, opkomsten af en teoretisk kultur i et nyt socialt lag (s. 272f.); mest tydelig som et bud på en generel, sociologisk forklaring er dannelsen af en gruppe af omvandrende, ikke-institutionsbundne intellektuelle i et felt af mindre bystater eller lokale magt- og befolkningscentre (s. 269), med en tilstrækkelig social kompleksitet og med (hvad jeg her vil kalde) en tilstrækkelig informationsteknologisk infrastruktur (altså et skriftsystem), og dog uden en overgribende stor-stats traditionelt etablerede, kulturelle institutioner (som i Egypten og

\footnotetext{
Omend man nok ikke skal undervurdere en effekt af 'populærfilosofi' (og 'populærreligion'?) i antikken, jf. fx omvandrende kyniske filosoffer (jf. Lang 2012, anmeldt i dette nr. af RvT).
} 
Mesopotamien). Dette lyder som et plausibelt scenarie. Uafgjort i Bellahs fremstilling er til gengæld, at med inddragelsen af Donalds 'teoretiske kultur' på et så tidligt tidspunkt kunne man forvente, at netop skriftlighed ville være nøglebegrebet til forklaring på aksetiden. Men lige netop på dette punkt bliver Bellah mindre end ganske klar. I kapitlet om aksetiden i det gamle Indien fremhæves tværtimod den indiske kulturs traditionelle mundtlige overlevering, i overensstemmelse med denne kulturs egne forestillinger, inklusive forbuddet imod overhovedet at nedskrive Rigveda (s. 482). Her synes kollektiv tekstbevarelse via mundtlig hukommelse og transmission at have opfyldt den funktion, som andre steder blev varetaget af etableringen af skriftlige arkiver. ${ }^{4}$ Paradoksalt nok er netop Nordindien det mest dramatiske eksempel på aksetid, i det mindste som religiøst fænomen og som praktisk afvisning af gældende religiøse konventioner (til forskel fra begyndende filosofiske særudviklinger). Der forbliver et uafgjort forhold her: Er aksetid grundlæggende et tidligt nedslag af Donalds teoretiske kultur? Eller indeholder aksetid, i det mindste i betydningen: et religiøst opgør med en religiøs herskende orden, også en selvstændig komponent, der i sin kerne er uafhængig af skriftlighed og dermed af teoretisk kultur?

\section{En sociologisk religionshistorie}

Det er formentlig sigende, at denne bog om religionens tidlige historie ikke er skrevet af en religionshistoriker. Hvorfor skriver religionshistorikere ikke en religionens historie? En overvejelse over dette spørgsmål kan sætte Bellahs bog ind i en akademisk-institutionel kontekst og være en passende baggrund for den nærmere omtale af hans bog.

Et af flere mulige svar på dette spørgsmål er, at de religionshistorikere, som beskæftiger sig med fortidige religioner, ofte er tynget af kompetencens åg og lærdommens dødvægt, og at de er paralyserede af risikoen for kritik fra specialister inden for andre områder end deres egne; allerede Mircea Eliade beklagede denne tilstand tilbage i begyndelsen af 1960'erne. ${ }^{5}$ Et andet muligt svar er, at mange nulevende religionshistorikeres forskningsmæssige kompetence, lærdom og interesse overvejende ligger i nutiden, mens kompetencen i religionernes historie mest rækker

$4 \quad$ Og denne forklaring har Merlin Donald i øvrigt stillet sig tilfreds med (Donald 2012, s. 73). - Jf. uklarheden i omtalen af aksetiden i Grækenland, s. 364, hvor Bellah ikke synes at differentiere imellem ekstern hukommelseslagring generelt og (alfabet-)skrift.

5 Eliade, 1961, 27-29. - Eliades lægemiddel imod religionshistoriens misere var ganske vist det stik modsatte af det, der giver sig med Bellahs udkast, nemlig at betragte historien og historisk bevidsthed, inkl. historiske forklaringer, som en fejlvisning, der kom ind i den vestlige kultur med den bibelske tradition, og i stedet fremhæve og anbefale, hvad han anså som den autentiske arv fra det før-bibelske: ritualernes og myternes cirkularitet, sådan som de endnu var bevarede i Østens visdom og naturfolks religioner. Med Bellahs bog er der nu et alternativ til det, som ikke kan undgå at virke som religionshistorisk kitch, og som dog medgiver det berettigede i Eliades kritiske udgangspunkt. 
til indførende undervisning. Med nutidsorienteringen kommer 'religionshistorien' imidlertid uundgåeligt til at række ind over det, der traditionelt er religionssociologiens gebet. Men hvis religionshistorikerne i grunden helst vil være religionssociologer, er det kun ironisk-retfærdigt, at det så er en religionssociolog, Robert Bellah, som må løfte den opgave, religionshistorikerne har ladet ligge.

Et tredje svar kan være, at mange (vel praktisk talt alle) religionshistorikere er skeptiske eller direkte afvisende over for et begreb om en 'religionens historie'. Den negative holdning skyldes formentlig en generel afvisning af relevansen af et begreb om evolution, når det kommer til kulturelle fænomener - $\mathrm{i}$ hvert fald til visse kulturelle fænomener. En typisk afværgemanøvre vil så være at insistere på en så eksakt definition af begrebet 'evolution' - fx vil der kunne spørges om, hvilken enhed det i grunden er, der undergår 'evolution'? - at begrebet netop ikke bliver anvendeligt for luftige sager såsom religion. Men selv humanister vil formentlig også medgive, at et begreb om evolution, uanset hvordan det så nærmere defineres, er umiddelbart meningsfuldt til forståelse af så menneskeskabte fænomener som redskabsteknologi, økonomi, byplanlægning, informationsteknologi, uddannelsesinstitutioner, politisk ledelse og meget andet. Der er formodentlig heller ingen religionshistoriker, som vil afvise teorien om en biologisk evolution. Men det medfører det paradoks, at evolution er et helt uproblematisk og ukontroversiel fænomen for alt andet end lige netop religion.

Hvorfor religionshistorikere indtager en negativ holdning til evolution inden for deres eget felt, er i sig selv et spørgsmål, der byder sig frem som emne for et forskningsprojekt. En af faktorerne er åbenlyst den såkaldte 'evolutionisme' i tiden op til 1. verdenskrig og dens eurocentristiske og/eller kristendomscentristiske fordomme (to faktorer, der ikke nødvendigvis, eller i det mindste ikke bevidst, er forbundne, som det fremgår af mange prominente forskere fra dén tid, bl.a. Frazer, Durkheim og Weber). Religionsforskningen efter 1 . verdenskrig blev først og fremmest inspireret af etnografi og antropologi (navne som Bronislaw Malinowski, Alfred R. RadcliffeBrown, Evans Evans-Pritchard, Claude Lévi-Strauss, Mary Douglas, Victor Turner, Clifford Geertz), dvs. af forskere, der formulerede generelle teorier om religion på grundlag af erfaringer med små samfund uden stat, udviklet arbejdsdeling og skriftsprog, dvs. samfund af en helt anden type end dem, i hvilke verdensreligionerne opstod og har eksisteret. Funktionalisme og navnlig symbolsystemsanalyse har givet uvurderlige bidrag til religionsvidenskaben, og religionsvidenskaben har ikke gjort noget forkert i at fundere sig på netop denne strømning. Men prisen herfor har nok ikke stået tilstrækkeligt klart. Etnografiens erkendelser har ikke kunnet bidrage til forståelse af religionernes historiskhed, hverken hvad angår religionernes forandring fra stammesamfundenes religionsformer til de tidlige statsdannelsers religioner, eller, og da her slet ikke, hvad angår de sidste to tusinde års dominerende religioner. I det etnografiske perspektiv vil religiøse forandringer kun kunne forstås som kalejdoskopiske transformationer, der kan gå i vilkårlig retning, altså en reel synkronis- 
me. ${ }^{6}$ Dette passer godt både for dem, der betragter alle religioner lige positivt, som lige fascinerende verdensforståelser (det ville være en 'Eliadesk' position), og for dem der betragter dem alle som lige irrationelle og overflødige. I sin konklusion forklarer Bellah, hvorfor hans eget begreb om metanarrativer og evolution ikke rammes af kritik for fx euro- eller kristendomscentrisme, for at homogenisere ikkevestlige kulturer eller for at lægge særlig vægt på Israel og Grækenland som de umiddelbare forløbere for den vestlige moderniseringshistorie (s. 597-600). Begrebet evolution inkluderer således ingen triumfalisme; det er overhovedet ikke sikkert, at biologisk og kulturel evolution ultimativt er af det gode. Også Bellahs bog må nødvendigvis ende på en dyster, øko-klimatisk eskatologisk note: Vi er lige midt i den sjette store artsudryddelseskatastrofe, en 'great dying', i jordens historie; men 'vores' udgave er den første, der er fremkaldt af en eneste arts overmåde succes (s. 601).

Hvad der ikke var plads til i den etnografisk inspirerede tænkemåde var præcist det historiske: at bestemte typer af religion, og bestemte religiøse fænomener, er afhængige af bestemte historiske omstændigheder, at visse fænomener forudsætter eksistensen af visse andre fænomener, og at disse relationer ikke er trivielle. Det er fx ikke trivielt, at skriftreligioner forudsætter skrift, dvs. eksistensen af et skriftsprog og en samfundsmæssig organisering, der muliggør eksistensen af en klasse af skriftlærde, inklusive den uddannelsesinstitution eller uddannelsespraksis, der er nødvendig for den fortsatte regeneration og opretholdelse af en sådan klasse henover generationer. ${ }^{7}$ Skrift og skriftkulturer er formentlig en betingelse for, at der overhovedet kan findes en eksplicit, selvbevidst 'teologi', altså en særlig diskurs med argumentation og polemik henover grænser og generationer, og med subtile, abstrakte begreber som det gode, det guddommelige, det menneskelige, liv, død, synd, erkendelse. De religioner, som har domineret de sidste to tusind år, de der upræcist kaldes 'verdensreligioner', er religioner, som ikke er bundet til en bestemt lokalitet, og som har deponeret en vigtig del af deres samlede 'informationsmængde' (hvis man kan bruge et sådant ord om moralske instrukser, formularer, fortællinger, digte og debatter) i tendentielt svulmede tekstsamlinger med tilsvarende biblioteker. If. denne næppe specielt udfordrende tese vil skrift være en vigtig del af forklaringen på, hvorfor visse religioner kvantitativt er kommet til at dominere, mens andre er blevet marginaliseret eller forsvundet eller har forvandlet sig til næsten ukendelighed og blevet

Michel Foucault formulerede forholdet meget præcist i en forelæsning om 'heterogene' rum fra 1967: I modsætning til 1800-talet er nutidens epoke rummets, samtidighedens epoke, hvor verden opleves ikke som en strøm i tiden, men som et sammenflettet netværk af forbundne punkter (en tanke der i 1980'erne blev dominerende i teorier om det postmoderne). - Reintroduktionen af biologisk og bio-kulturel evolutionsteori i 1990'erne og en påfaldende stigning i interessen for 'store historier' betød en tilbagevenden til 1800-tallets problemstillinger, om end ikke til den tids forklaringer.

I Gyldendals religionshistorie, 2011, forekommer ordene 'bogreligion' eller 'skriftreligion' ikke i registret; de er også fraværende i Gads Religionsleksikon (1999). Gyldendals religionsleksikon Religion/Livsanskuelse, 3. udg. 1998, har et stikord "skriftreligioner/skriftløse folkeslags religioner", der meddeler, at denne skelnen er "anvendt af nogle religionshistorikere", men at den ikke har vundet almindelig anerkendelse, da "primitive religioner ikke er dækkende karakteriseret ved skriftløshed". Det er vist et eksempel på, at hvad ikke alle har, må ingen have? 
til, eller er opgået i, disse 'verdensreligioner'. En sådan problemstilling burde stå central for religionshistorien; men den er helt uhåndterlig med redskaber hentet fra den ovennævnte klassiske antropologi. ${ }^{8}$

Skriftliggørelsen af religionen betyder jo ikke, at al religion herefter i et og alt er bestemt af skriftlighed. Skriften udrydder ikke nødvendigvis før-skriftlige kulturformer - også selv om skriftens egne forvaltere måtte have ønsket det, hvad der nok så ofte har været tilfældet. Med skriftligheden og det sociale lag af skriftkompetente opstår en ny form for sondring imellem elite og 'folk' - en sondring imellem dem, der er instrueret i den skriftlige religionsdiskurs og dem, som ikke er (sondringen mellem religiøs elite og ikke-elite i sig selv er ældre og formentlig ikke i samme grad knyttet til sondringen mellem skriftlighed og ikke-skriftlighed). ${ }^{9}$ Praksisser og forestillinger, der er blevet til og har kunnet eksisteret i skriftløse kulturer, fortsætter deres liv i en (ofte konfliktfyldt) samtidighed med skriftbaserede religionsformer. ${ }^{10}$

Opkomsten af de første skriftbaserede religionsformer og dermed også 'verdensreligionerne' finder sted i midten og sidste halvdel af 1 . årt. f.Kr., i den 'aksetid', som indgår i undertitlen i Bellahs bog; den seneste 'verdensreligion' af denne type er islam. Som sagt er emnet for Bellahs bog religion fra dens tidligste former op til og med aksetiden, eller op til aksetidens første udslag. I flere af kapitlerne kan man mene, at han lægger et for tidligt tidsligt snit imellem aksetid og hvad der følger. Under alle omstændigheder er bogens overordnede tese, at bestemte religiøse fænomener opstår i bestemte samfundsformer, bestemt af disses økonomiske, demografiske og politiske vilkår. Religionshistoriens gængse sondringer mellem religioner ud fra disses egne overleveringer og kulturelle homogenitet er derfor indlejret i en bredere kulturhistorisk epokalisering. Fx er egyptisk og mesopotamisk religion ikke primært præsenteret som selvberoende systemer hver med sit unikke verdensbillede og ethos, men som eksempler på den religionstype, som dannes og fungerer i tidlige, centraliserede stater med kongedømme, bydannelser og arbejdsdeling. Dette betyder også en slags tilbagekomst af kategorien 'naturfolks religion'. I en antropologisk funderede partikularisme havde denne ikke megen mening, eftersom hver enkelt af

8 Det bør retfærdigvis siges, at det omvendt er fra netop antropologisk side, at denne problemstilling har fået en afgørende inspiration, nemlig fra den britiske antropolog Jack Goodys forskning, jf. hans klassiker The Domestication of the Savage Mind, 1977, 36f.

9 Elite vs. ikke-elite er formentlig baseret på skellet i arkaisk religion imellem professionelle religiøse aktører ('præster') og andre ('menighed', om man vil). Selv om arkaisk religion bliver til i bystatskulturer og dermed er sammenfaldende med skriftsprogets tilblivelse, virker det ikke sandsynligt, at dannelsen af en elite har været organisk forbundet med skriftligheden. Skriftliggørelsen af kultiske tekster i Mesopotamien synes fx at være kommet til hundredevis af år senere end opkomsten af skrift, og skriftens primære formål var administration af materiel indkomst.

10 I den danske folkekirke har der været udbredt skepsis over for såkaldt 'folkereligiøse' tiltag som lysglober og pilgrimsvandring; denne modstand kommer givetvis primært fra mennesker, som er solidt indsocialiseret $\mathrm{i}$ deres religion via skriftlige tekster. For parterne $\mathrm{i}$ en sådan uenighed om legitimiteten af en bestemt praksis vil skriftligheden som sådan formentlig forekomme irrelevant. Mit argument her er, at den forestillingsverden, på hvilken modstanden imod 'folkereligiøs' praksis er baseret, kun er mulig i en skriftbaseret kultur. 
religionerne inden for dette felt kunne hævdes at besidde en egen identitet, der ikke adskilte sig fra de store religioner - alle var lige selvberoende og kulturelt homogene, alle besad samme grad af værdighed (hhv., hvis man så sådan på det, irrationalitet).

I Bellahs skema giver en kategori som naturfolks religion derimod god mening; for det, der holder religionerne sammen inden for en given kulturhistorisk, epokal kategori, er en kombination af det, religionerne i kategorien har til fælles, og det, hvori de er fælles om at adskille sig fra andre kategorier. Religioner i stammesamfund er fx ikke konstitueret ved eksistensen af centrale helligsteder med monumentalarkitektur, sådan som det er tilfældet med arkaisk religion, og arkaisk religion er ikke konstitueret i et fællesskab om en kontra-intuitiv lære, båret af en intellektuel elite, sådan som det er tilfældet med aksetidens religioner. Faktisk er negative kendetegn, altså fraværet af bestemte træk, det nok så vigtige ved en given epoke i den overordnede evolution: Som tribale religioner ikke har fx monumentalarkitektur, så er arkaisk religion ikke baseret på en generel distance eller afvisning af de materielle værdier, som dominerer såvel økonomisk som mere specifikt religionen. Her er det vigtigt for den rette forståelse af, hvad Bellah forstår ved evolution, at pointere, at senere epoker if. dette begreb ikke blot og simpelt afvikler tidligere epokers former; de lejrer sig over dem, indkapsler dem mere eller mindre, indgår i en eller anden form for symbiose. "Nothing is ever lost" (s. 267) er her den slagsordagtige spidsformulering, jf. at 'gennembrud ikke indebærer opgivelse af det, der tidligere var' (s. 278), analogt til den akkumulerede samtidighed i de psykologiske repræsentationsformer og i de Donaldske kulturfaser. Nye, og afgørende nye, ting kommer unægtelig til; bystaternes religionsform er ikke blot en variant af stammesamfundenes religion, egyptiske sakrale konger er ikke kun stammehøvdinge i grandiost format, hellige skrifter er ikke blot videreførelse af mundtlig overlevering med andre midler. Men de ting, der kommer til, er samtidig også videreførelser: bystaters ritualer varetager også funktioner, der er kontinuerlige med små-skala-samfunds ritualer, sakrale konger er også transformationer af høvdinge, helligskrifter fungerer også, ud over hvad de i øvrigt giver mulighed for, som videreførelse af en mytologisk tradition, der kunne være transmitteret mundtligt.

\section{Tribale og arkaiske religioner}

Den første fase i Bellahs overordnede skema for den kulturhistoriske evolution er som sagt stammesamfundenes religion (kap. 3: “Tribal religion: The production of meaning"): Det engelske tribal religion kan måske inspirere til det mere bekvemme adjektiv 'tribal' end det sprogligt klodsede 'stammemæssige' og dermed til betegnelsen 'tribal religion', altså religioner, som hører hjemme i jæger- og samlerkulturer samfund uden stat, uden markant arbejdsdeling, uden skrift. Bellah anfører tre eksempler, tre samfund fra forskellige steder på kloden: Kalapalo fra området omkring Xingu-floden i Brasilien, Walbiri fra den centrale ørken i Australien og Navajo fra 
Arizona, USA. På dette niveau dukker de individuelle religioner op igen, hver med deres særlige mytologier og livsførelsesregler - men altså her ikke beskrevet primært som selvstændige dannelser, men som eksempler på, hvordan religion typisk vil se ud i samfund med få medlemmer, svag politisk struktur, ingen bydannelse, arbejdsdeling eller skriftsprog. Disse tre tribale religioner har hver især særligt markante kendetegn, der vil være til stede i alle tribale religioner, men som i særlig grad er synlige i netop én af disse. Kalapalo tages som eksempel på en ritualform, der er baseret på musik, denne den måske mest basale sociale aktivitet, og på en social fundering i det rituelle, som svarer til Roy Rappaports bud på den elementære, sociale handling (jf. Lundager Jensen 2003; 2013). Walbiri illustrerer en ikke-stedsbundet, jæger-samler-kultur af den type, som Durkheim udså sig som den teknologisk og politisk mindst komplekse og derfor som den bedste illustration af det, han foreslog som religionens 'elementære', altså basalt-uomgængelige, komponenter og dens lige så basale funktion. Navajo-kulturen i dens kendte former siden Navajo'ernes migration til det nuværende territorium i Arizona er ganske vist langt fra en typisk jægerkultur. Men den rummer ikke desto mindre vigtige elementer til forståelse af jægerkulturers religion: I jagt-ritualer og -mytologi er jagten en tilbagevenden til en urtidslig, flydende identitet ('prehuman flux') mellem mennesker, dyr, planter og bjerge, hvori er indlejret jægerens rituelle skift mellem rovdyr- og menneske-identitet. ${ }^{11}$ Karakteristisk for tribale religioner er en rituelt-ekstatisk bekræftelse af en væsensidentitet mellem en gruppe mennesker og væsener fra en anden verden og af gruppens mytisk-normative grundlag; Bellah er her helt på linje med den vision om den 'elementære' religion, som Durkheim formulerede i Les Formes élémentaires i 1912. I forhold til den senere historie er det nemt at udpege, hvad tribal religion ikke rummer, hhv. - og mere betegnende for Bellahs generelle betoning af kontinuitet imellem faserne - hvad der kun rummes som ansatser. Den tribale religion, hvis primære funktion er at bekræfte og befordre en etableret orden (ikke kun social, men også ontologisk), indeholder ikke en klart optrukket kosmologi, en forestilling om personlige guder, der tilbedes, en individuel, moralsk kodet eskatologi, særligt religiøse institutioner ud over særligt trænede individer ('shamaner') eller et klart aftegnet forhold mellem religion og andre samfundsfunktioner.

Man kunne alternativt til 'tribal religion' operere med en kategori 'stenalderreligion'; men de tre eksempler, Bellah fremdrager, placerer sig forskelligt, hvad deres økonomiske basis angår. Mens Walbiri og jægertraditionen hos Navajo i så fald vil være 'palæolitiske' (ældre stenalder, jæger-samler-stenalder), lever Kalapalo delvis af en tidlig form for agerbrug, såkaldt horticulture, og har dermed i princippet allerede del i en neolitisk kultur ('bondestenalder'). Bellah giver ikke plads til en særlig neoli-

11 Bellah støtter sig her på Karl Luckerts forskning (vigtigst: The Navajo Hunter Tradition, 1975); allerede i 1986 var Luckerts forskning i øvrigt introduceret i en dansk sammenhæng: artiklen "Jægerkulturer og fænomenet skyld" i Religionsvidenskabeligt Tidsskrift 8, 1986 
tisk religionsform, altså en særlig fase af før-statslig 'agerbrugsreligion'; 12 i stedet har han særlig omtale af høvdingedømmer, hvor tribale kulturers grundlæggende egalitarisme er erstattet af stejle, sociale hierarkier, begrundet i slægtsskabsforhold (kap. 4: "From Tribal to Archaic Religion: Meaning and Power"). Sociologen Bellahs kriterium for epokeafgrænsningen er altså her politisk, ikke primært økonomisk, for det afgørende for den efterfølgende fase, arkaisk kultur, er netop etableringen af egentlige stater, ledet af konger. Den fundamentale ændring består derfor her i, at det tribale samfunds egalitarisme - som if. Bellah ikke er en uproblematisk tilstand, men resultatet af en konstant kollektiv overvågning og tøjling af alfa-individers rang til magtmonopolisering - bryder sammen som følge af voksende befolkningsmængde (der på sin side typisk skyldes agerbrugets fødevareoverskud) og deraf følgende nødvendigvis mere komplekse beslutningsprocesser, der kun kan finde sted i sociale hierarkier. Overgangsfasen er illustreret med oceaniske samfund, det i omfang og kompleksitet mindre Tikopia og det langt større og mere komplekse Hawaii. Tikopia har haft egentlige konger, som samtidig var præster, der forestod særlige ritualer i et fritliggende tempel ('open-air temple') med dyrkelse af guddomme; ritualernes formål er at sikre frugtbarhed og at opretholde de sociale hierarkier. Her er altså en række af de elementer til stede, der typisk vil indgå i en mere spontan forståelse af, hvad religion er: guder, dyrkelse, permanent helligsted, præster. Hawaii i den tilstand, kulturen havde i 1700-tallet, hvor den kom i kontakt med den vestlige verden, er eksempel på et samfund med en tidlig form for stat: et ekstremt hierarkisk samfund baseret ikke på slægtskabsrelationer, men på klasser: dels et aristokrati, dels en almindelig befolkning og dels en kaste af udstødte, med en despotisk og fjern øverste konge der i princippet inkarnerede et usynligt og ubevægeligt reservoir af frugtbarhedsbefordrende mana, med en udfoldet og systematisk gudelære og gudsdyrkelse foretaget af høvdinge, der var assisteret af særlige præster på udbyggede, permanente helligsteder, med organiseret krig og menneskeofre (der ses som karakteristisk for tidlige statsdannelser) og, ikke mindst, med en gruppe af mennesker, betegnet som 'profeter', der levede isoleret fra andre, permanent mentalt beskæftigede med religion og med inspireret evne til at forudsige dramatiske, politiske begivenheder. Hawaii udgør i Bellahs opstilling et veldokumenteret overgangsled mellem tribal og arkaisk kultur, som kan fungere som forklaringsnøgle for de langt mindre veldokumenterede dannelser af arkaiske samfund i Mesopotamien og i Indien (s. 214. 492). Hawaiisamfundet var allerede arkaisk, hvad de dominerende forestillinger, ritualer og institutioner angår, inklusive en officiel religion, der er vævet sammen med den politiske magt; men det manglede både den rationalisering af statsstyrelsen, som muliggøres af skriftlighed, og de omfattende bygningskonstruktioner, som er karakteristisk for en fuldt etableret arkaisk kultur.

12 I modsætning til fx Lang 2010, der regner med et 'tidlig-agrart' stade; jf. udførligt: Turner \& Maryanski 2008, 168-206. 


\section{Arkaisk religion}

Den fuldt udfoldede arkaiske religion (kap. 5: "Archaic Religion: God and King") illustrerer Bellah med tidlige, egentlige stater: Egypten og Mesopotamien ca. 3000 f.Kr. og Kina i midten af 2. årt. f.Kr. For andre eksempler (amerikanske højkulturer: Maya, Azteker, Inka, samt, Afrika [Nigeria] Yoruba) henviser Bellah til Brice Triggers bog Understanding Early Civilizations (2003). Arkaisk religion er en del af en stat, der er solidt etableret på urbanisering og arbejdsdeling. Her er det religion, ikke slægtskabsrelationer, der er udtryksform for social og politisk legitimering: Kongen er primært konge, fordi han er guddommeligt udvalgt og sanktioneret. En lang række typiske træk ligger i direkte forlængelse af den præ-arkaiske religionsform, der blev illustreret med Hawaii i dennes seneste fase: menneskeofringer (i arkaisk religions tidlige fase), distinkte gudeskikkelser og dramatisk mytologi og kongen som leder af både af religionsudøvelsen og af andre statsfunktioner, militære, administrative og juridiske. Religionen manifesteres med monumentalarkitektur i form af templer, som undertiden danner meget omfattende tempelkomplekser. Arkaisk religion er grundlæggende repræsentativ: Ritualer gennemføres med befolkningen som tilskuere, ikke som aktive deltagere, og tager form som specialiserede tempelritualer og storslåede processioner. En kompleks mytologisk verden kan nu formuleres og fastholdes i skrift. Redegørelserne for de tre udvalgte, arkaiske kulturers religion kan læses som brede indføringer, der inddrager en del 'normalt' stof; underligt nok, ikke mindst i betragtning af Bellahs eget teoretiske udgangspunkt i en variant af en Durkheimsk religionsforståelse, er den rituelle side af arkaisk religion i hans fremstillinger underbelyst i forhold teologi og mytologi. For mesopotamisk kulturs vedkommende fremhæver Bellah særligt den komplekse mytologi i værker som Atrahasis og Gilgamesh og de guddommeligt sanktionerede, etiske normer, som kongemagtens udførelse if. fx Hammurabis lov er underlagt. Mht. egyptisk kultur er Bellah bl.a. udførlig ang. de skiftende forestillinger, der omgav synet på forholdet mellem guder og konger og opkomsten af mytologisk spekulation blandt en skriftbeherskende elite. Særlig interessant i Kina er kontinuiteten fra en præ-arkaisk, egalitær varetagelse af forholdet til de døde, til den statslige, i sagens natur ekstremt hierarkiske, kejserkult, hvor en mere teoretisk øverste himmelguddom (Di, Shang Di, Tian) forbindes med dyrkelsen af deificerede kejserlige forfædre. Fælles for de arkaiske religioner er, at religion på den ene side bliver bogstaveligt talt meget synligt (ikke mindst arkitektonisk) som et særligt felt, og at der på den anden side er en gensidig solidaritet imellem religion og ledelse af resten af samfundet, typisk udtrykt $i$ at religiøse ceremonier varetages af kongen som den øverste kultleder eller af præster, der agerer på vegne af kongen. 


\begin{abstract}
Aksetiden
Det er dette, der ændrer sig grundlæggende i og med aksetiden - dvs. med de sammenlignelige, kulturelle fænomener, der forekommer inden for en omtrentlig tidsramme af nogle århundreder omkring midten af det første årt. f.Kr. i Kina, Indien og Grækenland. Normalt medregnes også det gamle Israels religion til aksetiden, selv om den tilsyneladende har manglet et ellers forekommende element: et bevidst og tydeligt afkald på materiel, jordisk rigdom og lykke. I et overgangskapitel (kap. 6: "The Axial Age I: Introduction and Ancient Israel") inddrager Bellah en række bidrag til diskussionen af aksetiden. ${ }^{13}$ Selve ideen om en aksetid er foregrebet med Max Webers begreb om en 'profetisk alder' og fremhævelsen af den historiske forudsætning for det moderne i verdensforsagende bevægelser i just midten af 1 . årt. f.Kr. ${ }^{14}$ Siden Karl Jaspers udmøntede begrebet er det blevet taget op af andre med forskellige bud på, hvori det 'aksiale' mere præcis består, såsom muligheden for intellektuel kritik af hidtil uproblematiserede antagelser (Arnaldo Momigliani) eller opkomsten af en 'anden-ordens-tænkning', dvs. refleksion over tænkning (Yehuda Elkana). Bellah selv ser opkomsten af teoretisk kultur i Merlin Donalds bio-kulturelle evolutionsskema som det mest nærliggende bud på en generel karakteristik. I bogens følgende kapitler om aksiale kulturer - Israel, Hellas, Indien og Kina - gives først fyldige beskrivelser af udviklingerne frem til deres respektive udgaver af arkaisk kultur som baggrund for identifikationen af, hvad der kan betragtes som aksialt, og diskussionen om, hvilke omstændigheder der i hvert enkelt tilfælde kan have befordret denne udvikling. Kapitlerne indeholder i sagens natur en mængde traditionelt stof, og de kan også læses som generelle religionshistoriske beskrivelser. Som sådan fungerer de generelt udmærket; at der vil være en mængde diskutable enkeltheder, adskiller dem ikke fra andre, tilsvarende fremstillinger.Det gamle Israel kan siges at have haft sin udgave af en proces hen imod det aksiale. Teoretisk tænkning er ganske vist knap nok til stede i GT (s. 283). Hvad der derimod er til stede, er etableringen af et polemisk alternativ til den omgivende nærorientalske og mediterrane verdens religiøse og politiske selvfølgelighed, et alternativ der funderer sig i etableringen af et skriftligt univers. Bellah vil, plausibelt nok, spore den polemiske front imod de omgivende samfunds polyteistisk sanktionerede kongedømmer tilbage til en 'Jahvealene-bevægelse' i 800-tallets Nordrige, inspiration for en senere 'deuteronomistisk revolution', hvis kerne er forestillingen om en særlig kontrakt mellem guddommen Jahve og folket Israel; 'pagten' var et revolutionært alternativ til et guddommeligt legitimeret kongedømme. Denne (anti-)politiske teologi flyder sammen med en konge-teologi i demokratiseret-egalitær udgave, hvor guddommens udvalgte, jordiske

3 Den introducerende del af kapitlet er omtrent identisk med Bellahs artikel fra 2005: "What is Axial about the Axial Age?"

14 I Max Webers kapitel "Zwischenbetrachtungen" fra Gesammelte Aufsätze zur Religionssoziologie (dansk oversættelse: "Indskudte betragtninger. Teori om religiøs verdensafvisnings stadier og retninger") in: Max Weber, Udvalgte tekster.
\end{abstract}


partner ikke er en enkelt person, men den kollektive størrelse 'Israel' Denne unikke konstellation fastholdes i en 'bog', hvormed israelitisk religion er forvandlet til en 'flytbar religion', en religion som kan overleve overalt på kloden' (s. 320).

I kap. 7 ("The Axial Age II: Ancient Greece”) er Grækenland det selvfølgelige emne; det er som bekendt her, det, der ofte omtales som transformationen fra 'mythos' til 'logos' - med Donalds kategorier: fra mytisk til teoretisk kultur - finder sted (idet man med 'transformation fra og til' bør forstå, at 'mythos' suppleres med 'logos'). Blandt forudsætninger for, at det netop var her, mere præcis i Athen, nybruddet fandt sted, kan regnes opkomsten af små bystater, på samme tid kulturelt forbundne og gensidigt konkurrerende, uden en overgribende, imperial stat som i Mesopotamien og Egypten, men styret igennem offentlig argumentation. Dertil kom en udpræget agonistisk-konkurrerende mentalitet, atletisk såvel som æstetisk. Med tragedien, der blomstrede i netop Athens politisk-økonomiske storhedstid i 400tallet, etableres en avanceret form for kollektiv selvrefleksion; tragedien er en politisk gruppes billede af sig selv (s. 355f.). Den græske filosofi, indbegrebet af 'logos' og af det aksiale i Grækenland, begynder som kosmologiske spekulationer, fremført af omvandrende 'intellektuelle', hvor hver enkelt anfægter ikke kun konventionelle forestillinger, men også sine konkurrenters alternativer (s. 365). Ud over fremkomsten af 'polis'-systemet, både som selvstændig bystat og som netværk af bystater, der var den afgørende forudsætning for det egentligt aksiale gennembrud, fra Sokrates og fremefter, blev udviklingen formentlig også fremmet af faktorer som skriftlighed, opkomsten af et pengesystem (med dertil hørende indlæring i abstrakt tænkning og teknologiske fremskridt, navnlig i det nye tempelbyggeri [s. 369-371]). ${ }^{15}$ Filosoffen Parmenides er central, for det er hos ham, man først ser 'teori' i betydningen 'at give grunde for, hvorfor noget skulle være sandt'. I slutningen af bogen (s. 577-579) vender Bellah tilbage til udviklingen af det græske begreb theoría, som i sig selv sammenfatter transformationen fra arkaisk tid til aksetid. 'Teori' betød typisk udsendelse af en person, en theorós, til et andet sted for at overvære en typisk rituel begivenhed, som kunne videreberettes i den udsendtes hjemby. Hos Platon, den aksiale transformations kulmination, betegner det samme ord en distanceret betragtning af et sagforhold, virkeligheden som den fremstår ikke for en naiv common sense-antagelse, men for den, der kan ræsonnere og abstrahere. En filosof er altså en person, der er sendt ud for med egne øjne at erkende, hvordan virkeligheden virkelig er. Dermed er filosofi, som Bellahs reference, Andrea Nightingale, forklarer (s. 579), karakteriseret ved aporía, dvs. hjemløshed, usikkerhed, atopía, dvs. en tilstand af ikke at høre til noget sted, og altså theoría, rejsen bort fra hjemmet for at komme til at (ind-)se. Men dette er i princippet grundlæggende den samme situation som andre kulturers ver-

Denne sammenhæng kan nævnes som eksempel på, at Bellahs bog også er en nyttig indføring, eller sammenfatning, af vigtige forskningsbidrag: om polis; Jean-Pierre Vernant, Geoffrey E.R. Lloyd; om skrift: Eric Havelock; om penge: Richard Seaford; om tempelarkitektur og søjlers geometri: Robert Hahn (nærmere litteraturhenvisninger i Bellahs noter). 
densforsagere, renouncers, som frakobler sig et normalt, socialt liv for i stedet at opnå en sandere erkendelse. Egentlige, praktiserende renouncers i den dramatiske stil, som opstod i Indien, finder Bellah ikke i den græske kulturssfære; men han nævner dog, ganske vist $\mathrm{i}$ en helt anden sammenhæng og en passant, kynikerne (s. 527), hvis rolle i udbredelsen af aksetidsforestillinger han formentlig undervurderer. ${ }^{16}$ Platon selv, if. Bellah, betød på den ene side et brud med al hidtidig tradition (s. 587). Men på den anden side er hans værk fuld af mimetiske og mytisk-narrative elementer, og hans planer for reform af samfundet var ikke så utopiske, at alting skulle erstattes af en ren 'teoretisk kultur', som under alle omstændigheder kun kunne være relevant for de få udvalgte; snarere gik hans forestillinger i retning af en 'hybrid kultur', en konstellation af mimetisk, mytisk og teoretisk (s. 394).

I Kina (kap. 8: "The Axial Age III: China in the Late First Millennium BCE") falder det aksiale gennembrud sammen med den politiske opløsning af en stabil, arkaisk samfundsformation (Zhou-dynastiet) i en periode fra midten af 1 . årt. f.Kr. af regionalisering og lokal krigsførelse (Forårs- og efterårsperioden, 722-476 f.Kr., og De Stridende Staters Periode, 475-221 f.Kr.). Der udvikler sig en tænkning, der med udgangspunkt i en kritisk distance til de givne forhold i den politiske verden forholder sig refleksivt til det individuelle liv generelt og til opfattelsen af politik, samfundsorden og religion; denne tænkning foregår i, eller giver anledning til dannelse af, indbyrdes konkurrerende skoler og sekter (s. 443), repræsenteret af omvandrende lærde og lærere (s. 425). Tænkningen tager nok udgangspunkt i et abstrakt-universelt begreb om mennesket som sådan og udvikler retningslinjer for, hvordan det individuelle menneske bør leve. Dermed bliver den, i kraft af et uundgåeligt paradoks, elitær, for det var i sagens natur kun få, der realistisk havde mulighed for at engagere sig i selvkultivering. Kong Fuzis svar på, hvad han oplevede som sin samtidige verdens leddeløshed (s. 420), var, at man burde vende tilbage til gamle og korrekte idealer og normer (fra Zhou-dynastiets tidlige epoke, begyndelsen af 1. årt. f.Kr.), inklusive en ritualiseret samfundsorden, hvor familiehierarkier afspejles i statens hierarkier, og som indbefatter korrekt gennemførelse af arkaiske, religiøse ritualer. Traditionalismen i dette program er ikke i sig selv aksialt; det aksiale er derimod både det kritiske udgangspunkt, oplevelsen af, at den sociale verden grundlæggende er i uorden, og midlet til reparation: et program for selvdannelse, som indbefatter et lære-discipelforhold (s. 411) og som installerer en selvreflekteret indstilling, som ikke ophæves ved vismandens efterfølgende engagement i den sociale og politiske verden. 'Daoismen' eller de forskellige retninger, der med større eller mindre ret kan sammenfattes under en sådan fælles term (Bellah er eksplicit om risikoen ved den bekvemme kategorisering af indbyrdes inkompatible tankegange, s. 411), blev et erklæret alternativ til kongfuzianismen. Hvor denne anbefalede fortidens konger og livet i de givne familiemønstre som idealer, anbefaler den daoistiske strømning mere radikalt-kritisk en markant individualisme, hvor individet tænkes uden for de tradi-

$16 \quad$ Se Lang 2012. 
tionelle, sociale sammenhænge, og en primitivisme, hvor det ikke er fortidens sociale normer, men naturen og verden, som den er - universets helhed, forud for kulturel prægning - som er modellen for et autentisk liv (s. 443). If. denne tankegang bør menneskelige handlinger være en slags 'ikke-handlinger' (wuwei), være som naturlige begivenheder, der er gode, sådan som de er, lige som ting, der sker i naturen, er gode nok, fordi de sker (det er vanskeligt ikke at associerer til visse tankegange i stoicismen). I og med sin 'naturalisme' kan daoismen sige meget om, hvad man ikke skal gøre; til gengæld er den ikke i stand til at sige, hvad man skal gøre (s. 455). Den daoistiske de-solidarisering med den naivt-ureflekterede, sociale verden kan tage skikkelse af eneboertilværelse (s. 437) og følelsesløs sindsligevægt over for egne og andre katastrofer og sorger (s. 447). De kinesiske aksiale former angår praktisk livsførelse og er formuleret aforistisk-anekdotisk. En særlig utilitaristisk-universalistisk retning, mohismen, der i lighed med kongfuzuianerne ville lede frem til deltagelse i samfundsstyrelsen, men i modsætning til denne ville afvikle familieloyalitet til fordel for ren statsloyalitet, indleder en rational debatform (s. 427). I sin gennemgang af Kina inddrager Bellah de vigtigste litterære værker: de kongfuzianske Analekter, den mohistiske Mozi, daoistiske skrifter som forløberen Yang Zhu og de centrale tekster Neiye, Zhuangzi og Daodejing samt de kongfuzianske Mencius (Mengzi) og Xunzi. Med disse former for aksialt gennembrud erstattes det arkaiske ideal om feudalistisk arvearistokrati til kongfuzianismens intellektuelle meritokrati; kejserriget vil ikke blive spændt ud og holdt oppe af krigere og godsejere, men af intellektuelle, der igennem selvkultiveringsforløb har lært at være i verden og uden for verden på samme tid.

Indien (kap. 9: "The axial age IV. Ancient India”, s. 481-566) er den sidste af de aksiale kulturer, der beskrives i bogen, og på en måde den mest interessante, for det er her, det aksiale fremtræder mest radikalt og spektakulært. Vejen dertil er, som i de andre kulturer, lang: fra Rigvedas frugtbarhedsreligion over den mellemvediske transformation med dens enormt elaborerede brahminske ritualer til de aksiale gennembrud i først upanishade-literaturen, dernæst i de ikke-brahminske renouncerbevægelser, hvoraf buddhismen kunne udvikle sig ud af den nationalt-indiske kontekst og realisere sine transnationale og trans-etniske potentialer. Denne historie er også en kultur- og socialhistorisk evolutionshistorie. Rigvedas kontekst er en kvægavlende, tribal samfundsformation, hvor materiel rigdom og social status er alt rigeligt. De store brahminske ritualer opstår som del af en potlach-agtig konkurrence mellem høvdingedømmer, hvor ritualerne skal sikre offerherren dennesidig status og hinsidig udødelighed. Samfundet er her i en tilstand som høvdingedømmet på Hawaii (s. 492), dvs. på vej til dannelsen af en arkaisk stat, med en kodificeret hierarkisering af samfundets medlemmer i form af varna-systemet af fire hierarkisk underordnede samfundsklasser, men endnu uden egentlig administration. Ritualerne har formentlig haft en sammenhængsstabiliserende funktion, typisk for tidligt-arkaiske samfund, og deres kolossale omfang kan virke som en funktionel erstatning for den 
monumentalarkitektur, som i Egypten havde et sammenligeligt formål (s. 501). Det aksiale gennembrud i Indien kom i to tempi. Første fase var Upanishade-litteraturen fra midten af 1. årt. og fremefter. Den mest fremtrædende lærde, Yajnalkaya, er her repræsentant for en kognitiv aksialitet (s. 518): En brahmin bør lære at opgive sit begær efter 'sønner, rigdom eller verdener', blive først som et barn, så en vismand, og til sidst, efter at have holdt op med at være nogen af delene, blive en (rigtig) brahmin. Yajnalkaya forlader faktisk koner og husstand og bliver en omvandrende tigger. Bruddet med alt, hvad der er indiskutabelt menings-, magt- og lystgivende if. den givne orden, er begrundet $i$ en erkendelse af, at alt er fuldt af lidelse. Men verdensudstigningen var et ideal for brahminer, som i fortællingerne om Yajnalkaya er begrundet $i$ en esoterisk erkendelse, dvs. funderet i en anerkendelse af en forudgiven, social struktur; den var ikke tænkt som en almen gyldig belæring, som alle burde eller kunne have indsigt i. Den anden fase, den etiske aksialitet, der fuldendte den aksiale transformation i Indien (s. 531), kom med det asketiske ideals universalisering igennem ikke-brahminske forsagelsesbevægelser. Disse etablerede sig som alternativer til den eksisterende orden: den arkaiske, inklusive den brahminske førstefase-aksialitet, som hvad den sociale etik angår fortsat var solidt arkaisk. Men bevægelserne etablerede sig også som alternativer til hinanden - helt enige om ikke at ville den verdensopfattelse og de livsformer, som var inkluderet i de vediskbrahminske orden, og helt uenige om, hvad der skulle sættes i stedet (s. 530). ${ }^{17}$ Blandt de indbyrdes konkurrerende, alternative retninger, der også omfattede materialister og nihilister, var det jainismen og buddhismen, som kunne skabe robuste traditioner; af disse koncentrerer Bellah sig om buddhismen som den historisk mest indflydelsesrige. Den brahminske renouncer fik sin konkurrent i den jainistiske og buddhistiske śramana, hhv. mere og mindre ekstrem mht. dramatisk, asketisk konsekvens. Også i buddhismen er alting lidelse; lidelsen skyldes begæret, der uundgåeligt er begær efter genstande og tilstande, der er underlagt foranderlighed; begæret skal derfor udslukkes; det sker ved at følge den buddhistiske lære. Men denne indsigt er ikke kun beregnet på nogle få udvalgte, eller en bestemt, mindre og højtrangerende samfundsklasse. Den skal ud til alle. Buddhaen bliver derfor en universel lærer med en lære, dharma/dhamma (s. 537), i lighed med Kong Fuzi og Platon (jf. s. 409. 575); de konsekvent aksiale religioner må formulere sig som uddannelsesprogrammer. Dharma/dhamma er ikke stands-etik, men universel etik, der i princippet, om end ikke i praksis, kan praktiseres af alle, uanset stand og nationalitet, og det er den oplystes pligt at udbrede sin indsigt til dem, der ikke har den. Buddhismen etablerede et system af dels praktiserende asketer, der forlod familie og økonomi, afviste

Bellah er ikke specielt udførlig på dette punkt; men det ville være mere nærliggende at udpege netop denne situation som den religiøse polemiks fødsel, end at mene - som en solid tradition fra David Hume til Jan Assmann (fx Assmann 2006) gør - at religiøs polemik historisk skulle være essentielt forbundet med netop (bibelsk) 'monoteisme'. Det potentielt konfliktuelle er formentlig ikke, at man holder noget bestemt for en kontroversiel og alternativ sandhed, men at man overhovedet insisterer på en sådan sandhed; og i så fald er det Indien, snarere end Israel, der er religionsstridighedernes vugge. 
ofringer og brug af ild og dermed madlavning (s. 535) og tiggede sig vej igennem livet, dels et lægfolk, som fortsat levede et liv i og med seksualitet, slægtskab og arbejde; det kunne opretholde asketerne, og for det gjaldt der mere realisable leveregler. I buddhismen samledes efterhånden de praktiserende verdensforsagere i en klosterbevægelse, som måske har været en inspiration for klostervæsenet i kristendommen, den eneste anden religion, der udviklede en solid monastisk tradition (s. 596). Med Maurya-riget og kong Ashoka (200-tallet f.Kr.) var skriftsprog en realitet også i Indien. Staten var baseret ikke længere på spektakulære og omkostningstunge ritualer, men på en professionaliseret administration, og statsmagten dekreterede religiøs tolerance, der formanede de stridende partier til at holde fred indbyrdes. Ashokas berømte edikter, skriftlige bekendtgørelser opsat på steler rundt omkring i det udstrakte rige, proklamerede et fredsprogram, der inkluderede statslig beskyttelse af alle religiøse retninger, brahminske såvel som ikke-brahminske; hvad forsagerne skulle forsage, var her ikke kun verdens materielle goder, men nu også fristelsen til højlydt at overvurdere deres egen retning og at nedvurdere andres (s. 548). Den brahminsk-funderede tænkning fastholdt sin forankring i den sociale lagdeling, hvor standsetik overtrumfer universel etik. Manus Lov er formentlig blevet til i en politisk usikker periode efter Ashoka som en brahminsk reaktion på den anti-brahminske askeses udfordring, og den integrerede askesen som et idealmoment for højkastefolk. I de episke mega-værker, Ramayana og Mahabharata, reflekteredes og diskuteredes den etiske udfordring af kastesystemet; udfordringen kunne ikke ignoreres, kastesystemet kunne ikke opgives. Som Bellah formulerer det: "later Indic civilization, perhaps more than most post-axial civilizations, was an uneasy compromise between axial and archaic cultural strands" (s. 559).

\section{Post-aksiale religioner?}

Ved at kortlægge de typiske religionsformer op til og med de aksiale gennembrud slutter bogen, hvor de store religioners historie begynder. Buddhismens begyndelse beskrives, men ikke kristendommens eller islams. Dermed munder bogen ud i åbne spørgsmål om, hvordan og i hvilket omfang aksiale momenter kom til at præge religionens historie op til nutiden. Bellah giver selv det plausible bud i form af en henkastet bemærkning, midt i kapitlet om Indien: “Every historical post-axial society has been a combination of axial and non-axial elements, and perhaps could not otherwise have functioned" (s. 523). Man kan nok trygt stryge "perhaps" - en ren og militant aksialitet vil jo frakende eksisterende sociale og politiske ordninger legitimitet, og en menneskegruppe uden økonomi, seksualitet, slægtskab og hierarkisk funktionsopdeling ville være et samfund af dyr eller af engle. Termen 'post-aksial' er til gengæld god: Buddhisme, kristendom og islam er tre forskellige udgaver af religiøs kompleksitet, inklusive uløselige dilemmaer og interne konflikter, der har formået at persistere, formentlig ikke på trods af, men netop på grund af deres kompleksitet. Det aksia- 
le persisterer i kraft af en alliance med det præ-arkaiske: det tribalt-effervescente og magiske og det arkaisk-ceremonielle, ligesom det præ-arkaiske persisterer i kraft af dets alliance med det aksiale, altså en abstrakt-tænkende, skriftkompetent elite, som er kultiveret ind i en 'teoretisk kultur'. Post-aksiale religioner har uden tvivl været både tribalt-arkaiske og aksiale, men aldrig uden brudflader ikke kun mellem det præ-aksiale og det aksiale, men også mellem det arkaiske og det tribale (gennemfører præsten en messe korrekt, eller er han god til at mane?), for ikke at tale om uundgåelige såvel inter- som intra-aksiale konflikter om det relevante bud på årsagerne til og konsekvenserne af den aksiale distance til det givne og om den nøjere udmøntning af den særlige aksialitet og om doseringen af denne i forhold til det tribale og det arkaiske. En beskrivelse af post-aksiale religioner må medtænke, at det aksiale kan undergå arkaisering, når fx et ritual, hvis erklærede indhold er et brud med det givne, uundgåeligt kommer til at fungere som en ny form for opretholdelse af det givne. Omvendt bør begrebet om en aksetid formentlig suppleres med et begreb om 'aksiale momenter' eller lignende: Det aksiale er en reaktion på en given orden, og aksiale kontraordeners konsolidering som normal-ordener vil fremkalde en endeløs række af ny-aksiale reaktioner, i den kristne tradition som asketiske reaktioner (fx cisterciensere, franciskanere), som reformationer og som et begreb som ecclesia semper reformanda. Og beskrivelsen gør sikkert klogt i ikke kun at knytte det tribale, det arkaiske og det aksiale til kognitive 'kulturer' (mimetisk, mytisk, teoretisk) eller til sociale niveauer og grupper ( $\mathrm{fx}$, meget groft sagt, 'folkelighed', myndigheder og teologer), men også til psykologiske momenter, behov og lyster i alle ikke alt for under- hhv. overstimulerede individer, sådan som Robert Bellah selv i bogens indledning inviterer os til.

Robert Bellahs Religion in Human Evolution bør være pligtlæsning for enhver, som vil tillægge historien i 'religionshistorie' en substantiel vægt. Men det vil den også være for enhver, som vil mene, at religionshistorien i sin natur er en komparativ videnskab. I sig selv peger komparation ganske vist i to modsatte retninger: til det, der er fælles for religioner og kulturer og som forbinder dem, og til det, der adskiller dem. Det komparative er ofte blevet anset som det særlige ved netop religionshistorien; men effekten har lige så ofte været en betoning af det forskelige, det særegne, det unikke ved hver enkelt religion; komparationens morale har her paradoksalt nok været altings usammenlignelighed. Effekten af Bellas bog bør efter min mening være, at den komparative sans og interesse for det, der ligner, det, der forbinder, det, der er det samme, bliver mindst lige så skarp. Det vigtigste at sige om fx babylonisk og egyptisk religion eller om fx buddhisme og kristendom er ikke kun, hvor meget de adskiller sig fra hinanden. For en komparativ videnskab er det mindst lige så vigtigt at påpege, og undersøge, hvordan de netop ikke gør det. Mesopotamisk og egyptisk religion var begge arkaiske religioner; buddhisme og kristendom er begge postaksiale religioner. I stedet for at lade begrebet 'naturfolks religioner' dekonstruere til en uoverskuelig mangfoldighed af fra små til bittesmå religioner, vil det være mere 
produktivt at gendanne begrebet, nu gerne som 'tribale religioner'. I en periode kan det fascinerende blive det trivielle og det trivielle det fascinerende. Det 20. århs. religionshistorie var fascineret af kulturelle forskelle ned i de mindste detaljer. Paradoksalt nok overtog religionshistorikere, der traditionelt ikke har stor sympati for teologer, dermed netop et teologiserende-nærsynet blik, der typisk er skarpt indstillet på minimale forskelle og ganske uinteresseret i massive ligheder. Det 21. århs. religionshistorie kan skifte fra mikroskop til kikkert og indlejre erkendelsen om kulturernes brogede mangfoldighed i en ny kulturhistorisk model, som ikke kun blændes af broget-fascinerende diversitet, men som også nøgternt og distanceret kan konstatere, hvor meget kulturer og religioner ligner hinanden. Ikke i al almenhed, som via religionsfænomenologien, men historisk-epokalt, $\mathrm{fx}$, som en god begyndelse: tribalt, arkaisk, aksialt og post-aksialt.

\section{LITTERATUR}

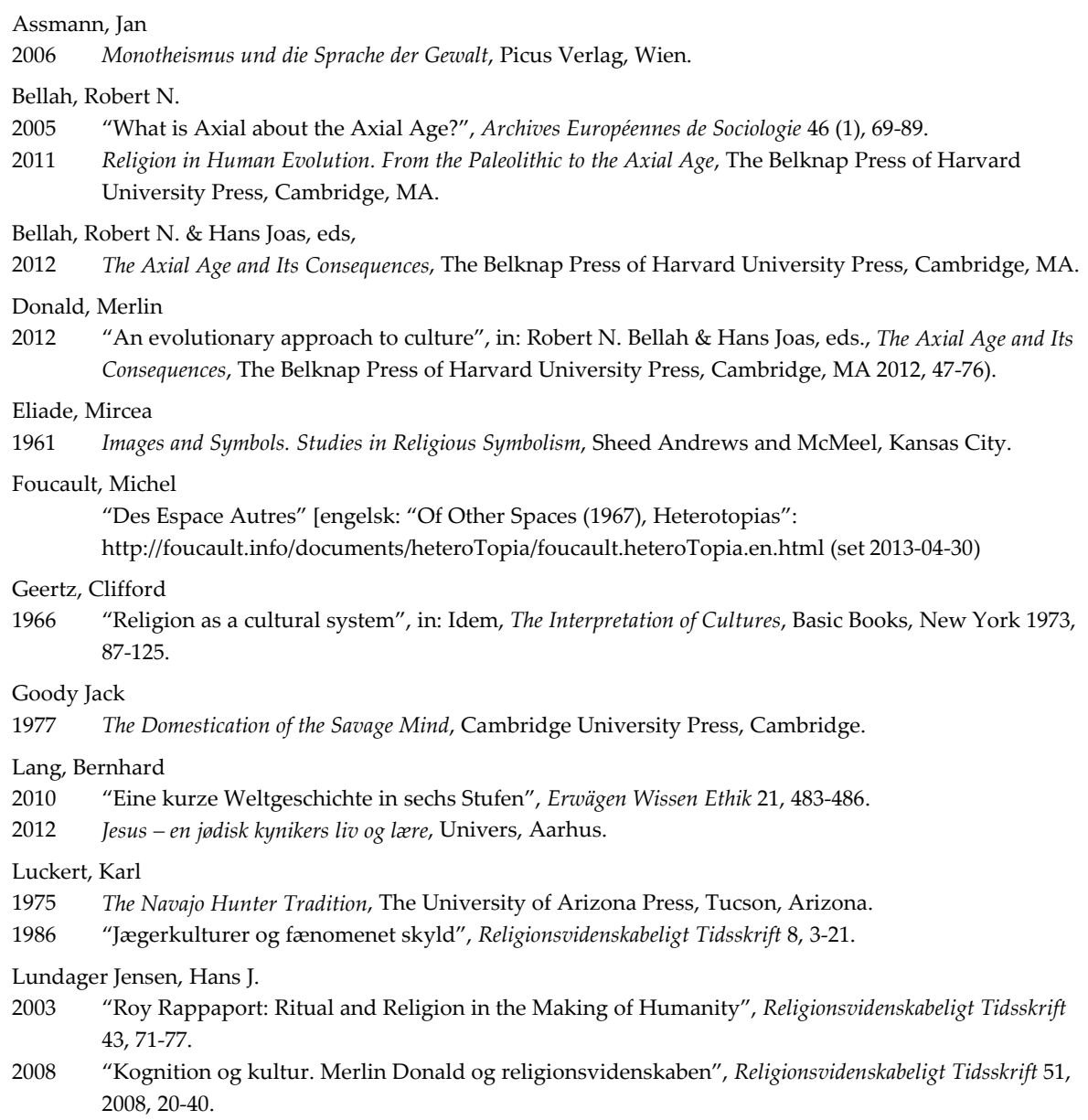


2011 "Religionshistorie og aksetid. Om Robert Bellahs udkast til en evolutionær religionshistorie", Religionsvidenskabeligt Tidsskrift 56, 5-22.

2013a "Noter/Kommentar til Roy A. Rappaport: “The Obvious Aspects of Ritual” : Arbejdspapir til undervisning i Forskningshistorie":

http://pure.au.dk/portal/files/51255992/HJLJ_Rappaport_Oby_Asp_notat_2012_12_03.pdf.

Nielsen, Klaus Bo,

2008 "Xunzis ritualanalyse", Religionsvidenskabeligt Tidsskrift 51, 41-57

2012 Kinesisk religion og livsanskuelse fra arkaisk til moderne tid, Aarhus Universitetsforlag, Aarhus.

Trigger, Bruce

2003 Understanding Early Civilizations. A Comparative Study, Cambridge University Press, Cambridge.

Turner, Jonathan H. \& Alexandra Maryanski

2008 On the Origin of Societies by Natural Selection, Paradigm Publishers, Boulder, CO.

Weber, Max

1920 "Zwischenbetrachtungen" fra Gesammelte Aufsätze zur Religionssoziologie [dansk oversættelse: "Indskudte betragtninger. Teori om religiøs verdensafvisnings stadier og retninger" in: Max Weber, Udvalgte tekster bd. 1, Hans Reitzels forlag, København 2003, 321-357].

Hans J. Lundager Jensen, professor, dr.theol. Religionsvidenskab, Aarhus Universitet 